\title{
Push-Out Tests for a Novel Prefabricated Steel-Concrete Composite Shallow Flooring System
}

\author{
I.M. Ahmed ${ }^{a}$, K.D. Tsavdaridis ${ }^{\text {b* }}$, F. Neysaric ${ }^{\text {and J.P. Forth }}{ }^{d}$ \\ a PhD Candidate, School of Civil Engineering, University of Leeds, UK \\ ${ }^{\mathrm{b}}$ Associate Professor of Structural Engineering, School of Civil Eng., University of Leeds, UK \\ c Technical Director, Mason Clark Associates, Millshaw Business Living, Global Ave, Leeds, UK \\ ${ }^{\mathrm{d}}$ Professor in Concrete Engineering and Structures, School of Civil Eng., University of Leeds, UK \\ * e-mail address: k.tsavdaridis@,leeds.ac.uk
}

\begin{abstract}
This paper introduces a novel prefabricated and shallow steel-concrete composite flooring system which is consisted of two main structural components: two C-channel steel beams and a partially encased concrete floor. The concrete floor, which is in the form of T ribbed slab sections, was constructed using two types of concrete (reinforced normal concrete and reinforced lightweight aggregate concrete). The steel edge beams partially encase the floor slab and provide clear and straight finish edges. The floor slab spans to a maximum of $2.0 \mathrm{~m}$ inclusive of the width of the steel edges with a finished depth of only $230 \mathrm{~mm}$. The unique features of the proposed system are reducing the weight and the number of erection lifts (during installation) by using lighter elements (lightweight concrete and shallow steel beams) while the wider possible units have been proposed to fit on transportation tracks; further reducing the extent of site works by pre-off site fabrication, examining the material cost against the fabrication and site erection costs. For the composite slab in bending, the longitudinal shear force is transferred by a unique shear mechanism which results from the special shear connectors. This paper includes the work of a total 2 full-scale push-out tests aimed at investigating the longitudinal shear behaviour of these novel flooring systems and the effects of additional shear connectors. An analytical work is also carried out to investigate the failure mechanism of the system.
\end{abstract}

Keywords: shear connectors; web-welded studs; flooring system; push-out test; lightweight aggregate concrete.

\section{Introduction}

In recent years, the increasing demand for prefabricated and lightweight shallow flooring systems had led to the wide use of the hollow core precast floors and Cofradal floors. However, the span and width of these flooring systems with a depth of $250 \mathrm{~mm}$ are up to $8.0 \mathrm{~m}$ for Cofradal floor and $9.5 \mathrm{~m}$ for hollow core precast units with a width of $1.2 \mathrm{~m}[1,2]$. One way of achieving floor longer spans is to use composite beams [3, 4]. The proposed flooring system [5] is a new prefabricated type of steelconcrete composite flooring system which consists of T-ribbed slab sections constructed using reinforced lightweight aggregate concrete and two C-channel steel edge beams which encapsulate the floor slab in the middle while providing clean and straight finish edges, as shown in Figure 1.

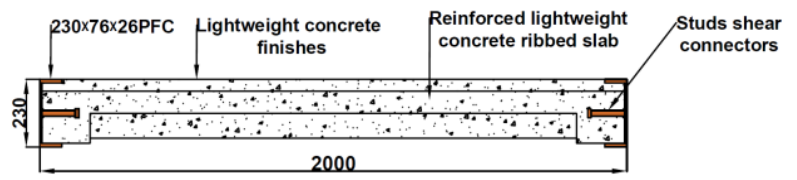

Fig. 1. Schematic drawing of a cross-section of the new flooring system.

The floor slab width is $2.0 \mathrm{~m}$ inclusive of the width of the steel edge with a finished depth of $230 \mathrm{~mm}$. The new flooring system can span up to $11.0 \mathrm{~m}$. The total weight of the floor is reduced by having voids running from one side to the other side of the T-ribbed slab. The proposed flooring system reduces the weight and the 
number of erection (installation) lifts by using lighter elements (lightweight concrete and steel members) and the wider possible units, as well as reduces the extent of site works by pre-off site fabrication by examining the material cost against the fabrication and site erection costs being proportionally in the order of $35 \%$ and $65 \%$, respectively.

The proposed flooring system exercises the sustainability approach in the selection of its components using sustainable materials such as lightweight aggregate concrete (Lytag aggregate) and lightweight steel members. An analytical Life cycle assessment for the proposed flooring system was developed and compared with other prefabricated flooring system (Cofradal slab) [5, 6]. Form the study it was found that the proposed flooring system reduces the embodied energy and embodied carbon by about $17.94 \%$ and $9.33 \%$ respectively when compared with the Cofradal slab.

As the proposed flooring system is being cast in the shop, the dowel and web-welded stud pass from one side to another side along the width of the flooring system and are connected to the steel beams. These studs and dowels form a unique mechanism for transferring longitudinal shear forces along the flooring system. The aim of this research is to investigate the behaviour and properties of this shear transfer mechanism by conducting a series of push-out tests.

\section{Objectives}

In order to provide information on the behaviour and properties of this unique shear transfer system the objectives of this research are as follows:

- To design the specimens to fit this new type of push-out tests that represent the actual shear behaviour;

- To design the push-out tests that reflect the desired loading condition and are in compliance with the specifications of the Eurocode 4 (EN 1994-1-1:2004) [7];

- To analyse the characteristic behaviour of these shear connectors from the load-slip curves;

- To examine the test results and propose a conceptual model as well as a design approach for the shear behaviour.

\section{Shear resistance}

The fundamental purpose of the shear connector is to transfer the longitudinal shear force and to resist the transverse separation force. The shear connectors used in the new flooring system are different in form compared with the conventional shear studs employed in steel-concrete composite flooring systems. They innovatively incorporate dowels and horizontal studs' features of the flooring system. One type of shear connectors investigated in this paper is the combination dowels and web-welded stud shear connectors with two different types of concrete (normal and lightweight aggregate concrete).

\subsection{Dowels and web-welded shear stud connectors}

One of the functions of these dowels is to provide a tying force for the edge steel channels. Generally, high yield dowels are welded to the web of the steel edge beam, passing through the centre of slab ribs. The two dowels you positioned at every $870 \mathrm{~mm}$, as shown in Figure 2 . The studs were positioned at every $435 \mathrm{~mm}$ passing through the thin slab. The dowels and shear studs simultaneously resist the longitudinal shear forces.

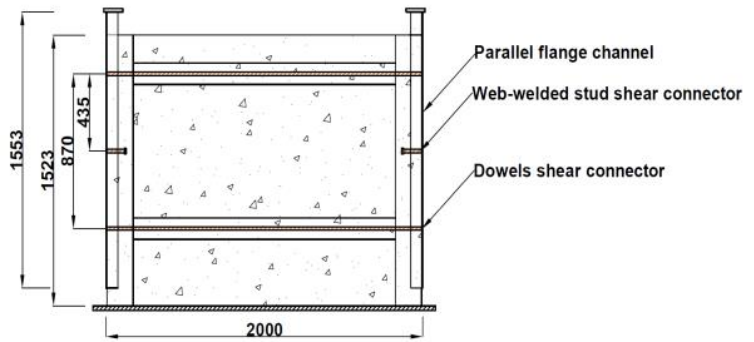

Fig. 2. Dowels and horizontal shear studs connectors.

\section{Push-out tests}

In the push-out test, shear forces are applied directly to the shear connectors. The characteristic behaviour and shear resisting properties of any particular shear connectors or their combination are examined. A series of push-out tests were carried out to investigate this novel shear connection system.

\subsection{Design details of test specimens}

C-channel steel sections used for the push-out tests of $230 \times 75 \times 26$ PFC, as shown in Figure 3. Two dowels and two shear studs (one on each channel) were welded to the beam webs. The shear-resisting capacity and the type of shear connectors are investigated, while the distance 
between dowels and shear stud has been kept wide to avoid any interaction between them.

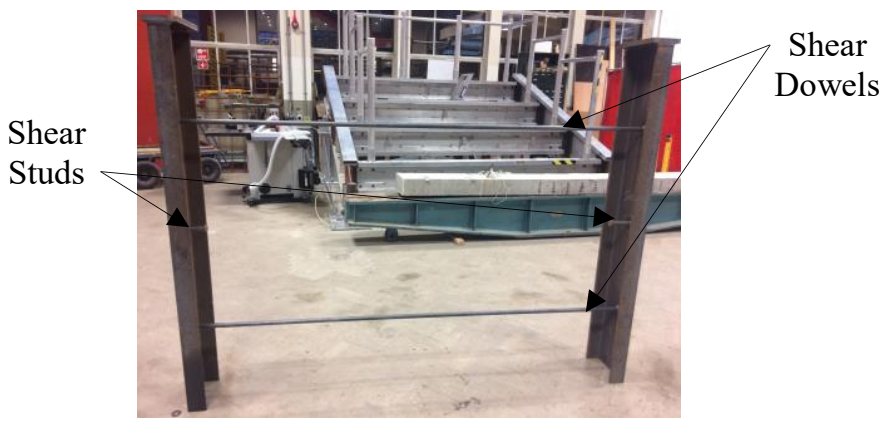

Fig. 3. The steel section with the shear connectors.

Two types of concrete material were used for the slabs, normal concrete and lightweight aggregate concrete. The former has a higher compressive strength than the latter one. Brief descriptions, numbering and dimensions of the specimens are summarized in Table 1.

Table 1. Brief descriptions and numbering of the specimens.

\begin{tabular}{|c|c|c|c|c|c|}
\hline $\begin{array}{l}\text { Test } \\
\text { gro } \\
\text { up }\end{array}$ & $\begin{array}{c}\text { Concret } \\
\text { e type }\end{array}$ & $\begin{array}{l}\text { Speci } \\
\text { men } \\
\text { No. }\end{array}$ & $\begin{array}{l}\text { Slab } \\
\text { width } \\
(\mathbf{m m})\end{array}$ & $\begin{array}{c}\text { Slab } \\
\text { depth } \\
(\mathbf{m m}) \\
* *\end{array}$ & $\begin{array}{c}\text { Total } \\
\text { length } \\
\text { of } \\
\text { specim } \\
\text { en } \\
(\mathrm{mm})\end{array}$ \\
\hline $\mathrm{T} 1 *$ & $\begin{array}{l}\text { Normal } \\
\text { (NC) }\end{array}$ & $\begin{array}{l}\text { T1- } \\
\text { NC }\end{array}$ & 2000 & 230 & 1653 \\
\hline & $\begin{array}{c}\text { Lightwei } \\
\text { ght } \\
\text { (LWC) }\end{array}$ & $\begin{array}{l}\text { T1- } \\
\text { LWC }\end{array}$ & 2000 & 230 & 1653 \\
\hline \multicolumn{6}{|c|}{$\begin{array}{l}\text { T1* dowels with web-welded stud shear } \\
\text { connector } \\
\text { The slab surfaces are flush with flanges of } \\
\text { the steel section }\end{array}$} \\
\hline
\end{tabular}

\subsection{Test procedure}

Push-out tests were carried out in the Heavy Structures Laboratory of the University of Leeds. The test rig and set up are shown in Figure 4. One identical hydraulic jack was used to apply a load, with a capacity of $1000 \mathrm{kN}$. Load levels were measured using a load cell and the longitudinal slip and transverse separation were measured using dial gauges of $0,01 \mathrm{~mm}$ resolution.

Prior to the tests, the specimens were bedded in using a steel plate, which resulted in an even contact with the reaction plate. The incremental monotonic load was applied; the duration of the push-out tests was around 2 hours with a load rate of $0.5 \mathrm{kN} / \mathrm{sec}$, which are satisfied with the requirement of not less than 15 minutes duration, specified in the Eurocode 4 [7].

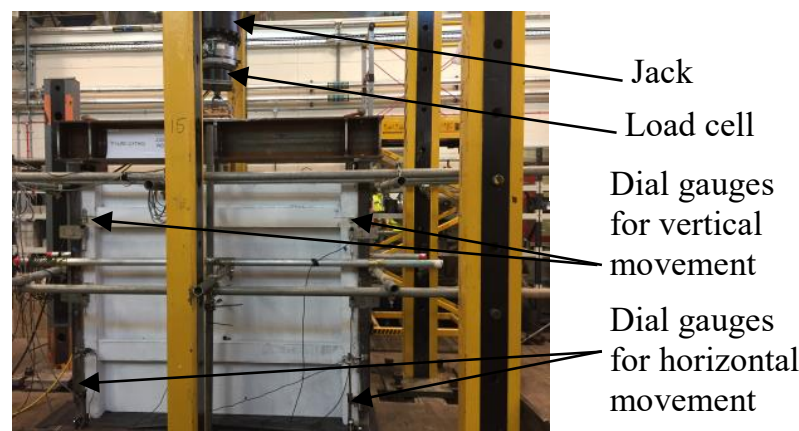

Fig. 4. Testing apparatus.
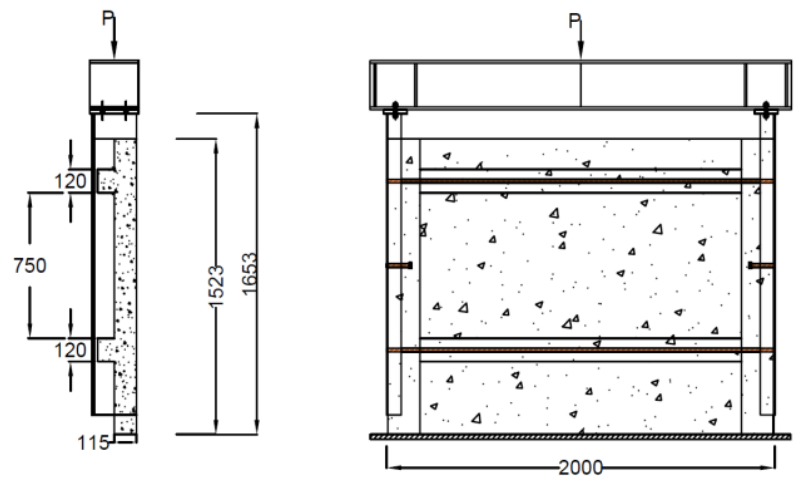

Fig. 5. Drawing of test T1.

\section{Results}

\subsection{Load-slip curves}

The load-slip curves obtained from the pushout tests represent the characteristic behaviour of the shear connectors. Load-slip curves of specimens of each test group are shown in Figures 6 and 7. The failure load of every shear connector has been recorded.

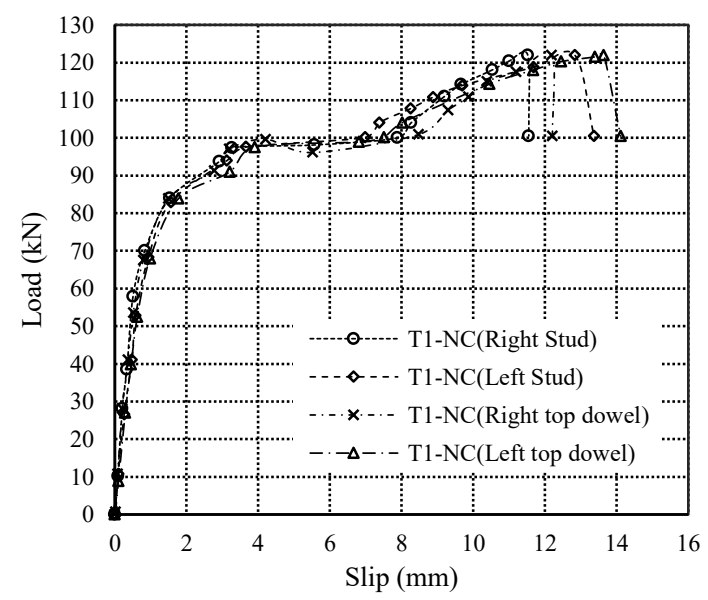

Fig. 6. Load-slip curves of specimen T1-NC, dowels with web-welded stud. 


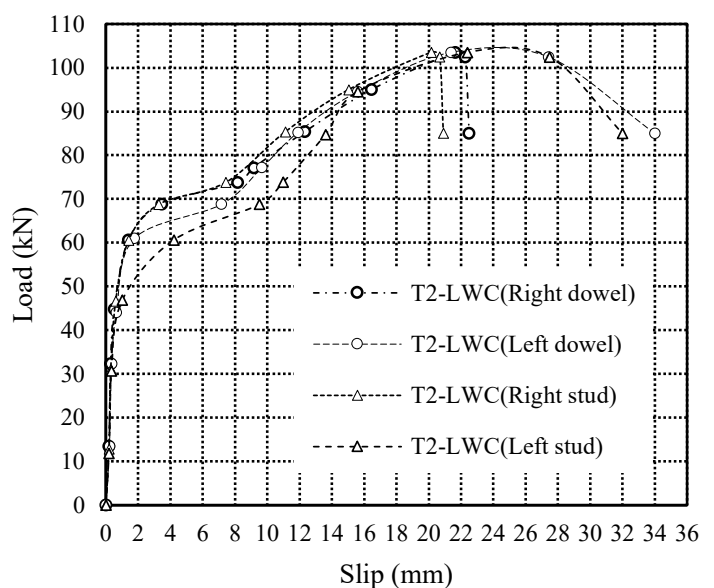

Fig. 7. Load-slip curves of specimen T1-LWC, dowels with web-welded stud.

\subsection{Behaviour analysis}

\subsubsection{Specimens with normal concrete}

A uniform behaviour of the dowel at both sides of the specimen was observed by the specimen T1-NC. Elastic deformation was followed by plastic deformation and post-failure plastic deformation while dowel shear connectors on the left hand side of the specimen show some post-failure strength with extensive slip. This was due to the presence of dowel which resisted the vertical movement of the steel section. The same dowels were sheared off with bending near their ends at load of $730 \mathrm{kN}$ on the left hand side of the specimen. This was due to the distribution of stresses over the slab width during the test which results in stress concentration on the left hand side of the specimen. Similar behaviour was observed by the stud shear connectors. Elastic deformation was followed by plastic deformations and postfailure plastic deformation took place but the shear stud connector on the left hand side of the specimen showed post-failure strength with extensive slip. The shear stud on the left hand side of the specimen was sheared off near its root at approximately $700 \mathrm{kN}$, however, the shear stud on right hand side of the specimen was only bended without shearing off. Overall, the stud dowels on the right hand side are deformed plastically while the stud and dowels on the left hand side are deformed and sheared off. The stud was failed first then the top dowel near form the load was failed which followed by the failure of the bottom dowel.

\subsubsection{Specimens with light-weight concrete}

A uniform behaviour of the dowel shear connector at both sides of the specimen was observed by the specimen T1-LWC. Elastic deformation was followed by plastic deformations and post-failure plastic deformation but the dowel shear connectors on the left hand side of the specimen shows postfailure strength with extensive slip. This was due to the presence of the dowels resisting the vertical movement of the steel section. The dowels on the left hand side of the specimen were sheared off with bending near the ends (welding) at $621 \mathrm{kN}$. However, the dowels on the right hand side of the specimen were only bended without shearing off. This was due to the distribution of stresses over the slab width which results in local stress concentration on the left hand side of the specimen. The same behaviour was found by the stud shear connector. Elastic deformation was followed by plastic deformation and post-failure plastic deformation was observed while the shear stud connector on the left hand side of the specimen showed post failure strength with extensive slip. The shear stud on the left hand side of the specimen was sheared off near its root (welding) at $440 \mathrm{kN}$, however, the shear stud on right hand side of the specimen was only bended without shearing off.

\subsection{Evaluation of results}

The properties of the shear connectors were evaluated from the results of the push-out tests, and are summarised in Table 3 and 4. The concrete strength of the specimens is listed in Table 2.

Table 2. Concrete strength of the specimens.

\begin{tabular}{ccc}
\hline Specimen No. & $\begin{array}{c}\text { Compressive } \\
\text { Strength } \\
\text { (MPa) }\end{array}$ & $\begin{array}{c}\text { Tensile } \\
\text { Strength } \\
\text { (MPa) }\end{array}$ \\
\hline T1-NC & 37.3 & 2.45 \\
\hline T1-LWC & 36.8 & 2.12 \\
\hline
\end{tabular}

- The ultimate shear capacity of the shear connector, $\mathrm{Pu}$, was obtained by dividing the ultimate load of the specimens by the number of the shear connectors.

- The slip capacity of the shear connector, $\delta u$, was the slip value at the load level dropped by $10 \%$ below the ultimate load (EC4, EN1994-11: 2004). Where the shear connectors have no plastic deformation after maximum load is reached, the slip capacity is the slip value at the maximum load level. 
Table 3. Result evaluations of the shear connectors of the specimens.

\begin{tabular}{cccc}
\hline $\begin{array}{c}\text { Specimen } \\
\text { No. }\end{array}$ & $\begin{array}{c}\text { Ultimate } \\
\text { shear } \\
\text { capacity, } \\
\boldsymbol{P}_{\boldsymbol{u}}, \\
(\mathbf{k N})\end{array}$ & $\begin{array}{c}\text { Shear } \\
\text { Connectors }\end{array}$ & $\begin{array}{c}\text { Slip } \\
\text { capacity, } \\
\boldsymbol{\delta}_{\boldsymbol{u}}(\mathbf{m m})\end{array}$ \\
\hline T1-NC & 121.9 & Right dowel & 12.18 \\
& 121.9 & Right stud & 11.52 \\
& 121.9 & Left dowel & 13.64 \\
T1-LWC & 121.9 & Left stud & 12.83 \\
& 103.51 & Right dowel & 15.47 \\
& 103.51 & Right stud & 14.95 \\
& 103.51 & Left dowel & 14.13 \\
& 103.51 & Left stud & 14.25 \\
\hline
\end{tabular}

Table 4. Complement of result evaluations of the shear connectors of the specimens.

\begin{tabular}{|c|c|c|c|c|c|}
\hline $\begin{array}{c}\text { Speci } \\
\text { men } \\
\text { No. }\end{array}$ & $\begin{array}{l}\text { Shear } \\
\text { Conne } \\
\text { ctors }\end{array}$ & $\begin{array}{l}\text { Charact } \\
\text { eristic } \\
\text { slip } \\
\text { capacity, } \\
\quad \delta u k, \\
(\mathrm{~mm})\end{array}$ & $\begin{array}{c}\text { Stiffn } \\
\text { ess, } \\
K, \\
(\mathbf{k N} / \\
\mathbf{m m})\end{array}$ & $\begin{array}{c}\text { Ductilit } \\
\text { y } \\
\text { classific } \\
\text { ation } \\
\text { (pass/fa } \\
\text { il) }\end{array}$ & $\begin{array}{c}\text { Tie } \\
\text { resist } \\
\text { ance } \\
\text { check } \\
\text { (pass/ } \\
\text { fail) }\end{array}$ \\
\hline \multirow[t]{4}{*}{$\begin{array}{l}\text { T1- } \\
\text { NC }\end{array}$} & $\begin{array}{l}\text { Right } \\
\text { dowel }\end{array}$ & 10.96 & 10.0 & pass & pass \\
\hline & $\begin{array}{l}\text { Right } \\
\text { stud }\end{array}$ & 10.36 & 10.58 & pass & pass \\
\hline & $\begin{array}{c}\text { Left } \\
\text { dowel }\end{array}$ & 12.27 & 8.93 & pass & fail \\
\hline & $\begin{array}{l}\text { Left } \\
\text { stud }\end{array}$ & 11.55 & 9.50 & pass & fail \\
\hline \multirow[t]{4}{*}{$\begin{array}{l}\text { T1- } \\
\text { LWC }\end{array}$} & $\begin{array}{l}\text { Right } \\
\text { dowel }\end{array}$ & 13.92 & 6.69 & pass & pass \\
\hline & $\begin{array}{l}\text { Right } \\
\text { stud }\end{array}$ & 13.45 & 6.92 & pass & pass \\
\hline & $\begin{array}{c}\text { Left } \\
\text { dowel }\end{array}$ & 12.71 & 7.32 & pass & pass \\
\hline & $\begin{array}{l}\text { Left } \\
\text { stud }\end{array}$ & 12.82 & 7.26 & pass & pass \\
\hline
\end{tabular}

- Characteristic slip capacity, $\delta u k$, is the slip capacity reduced by $10 \%$. If it is greater than $6 \mathrm{~mm}$, the shear connector is classified as ductile [4]. Furthermore, the load-slip curve of the shear connector should show plastic deformation after the maximum load is reached.

- The stiffness of the shear connector, $\mathrm{K}$, was the linear stiffness of the load-slip curves.

- The criterion of tie resistance check is that the transverse separations at $80 \%$ of the ultimate load should be less than half of the slip at that load level (EC4, EN1994-1-1: 2004).

The results of test group T1 showed that the shear resisting capacity of the shear connector increased with the increase of the concrete strength. The failure load of the specimen with higher strength of concrete (T1-NC) was higher than that of the specimen with lower strength of concrete (T1-LWC), respectively. This comparison was based on the same type of shear connectors.

The slips of the dowel and stud shear connectors welded to the web were significant at the ultimate load, between $11-13 \mathrm{~mm}$ for T1-NC specimen, and between 14-16mm of T1-LWC specimen. The slip stiffness of the dowel and shear stud connectors among the two specimens was somewhat different. It was demonstrated that the slip stiffness was influenced by the strengths of concrete. The separations at the ultimate loads were $5.0 \mathrm{~mm}$ for $\mathrm{T} 1-\mathrm{NC}$ specimen and $2.7 \mathrm{~mm}$ for T1-LWC specimen, respectivley.

\subsection{Failure mechanism}

The failure of T1-NC specimen was near the top dowels' position around the rib in both sides at approximately $600 \mathrm{kN}$. The cracks continued towards the position of the dowel connectors in the vicinity of the ribs. Then the concrete near the studs' position started cracking at approximately $620 \mathrm{kN}$. These cracks continued towards the poition of the shear studs. Then the concrete near the bottom dowels' position started cracking at a load of approximately $640 \mathrm{kN}$. The cracking noise was initially heard at the end of the elastic deformations and it was then intensified during the plastic deformations. A sudden "bang" failure took place at the end of the test, as the top and bottom dowels and the shear stud on the left hand side were sheared off.

The failure of T1-LWC specimen started with concrete cracking near the top dowels' position in the vicinity of the rib in both sides at approximately $390 \mathrm{kN}$. These cracks continued towards the poition of the shear studs. Then the concrete near the bottom dowels' position started cracking at approximately $440 \mathrm{kN}$. The cracking noise was initially heard at the end of the elastic deformations, and it was then intensified during the plastic deformations. A sudden "bang" took place at the end of the test, as the top and bottom dowels and the shear stud on the left hand side were sheared off.

The width and the number of cracks which observed from specimen T1-LWC were more than the number and width of cracks of specimen T1-NC, as shown in Figures 8 and 9. This was anticipated as the lightweight concrete is weaker than normal concrete in resisting the longitudinal shear force. 


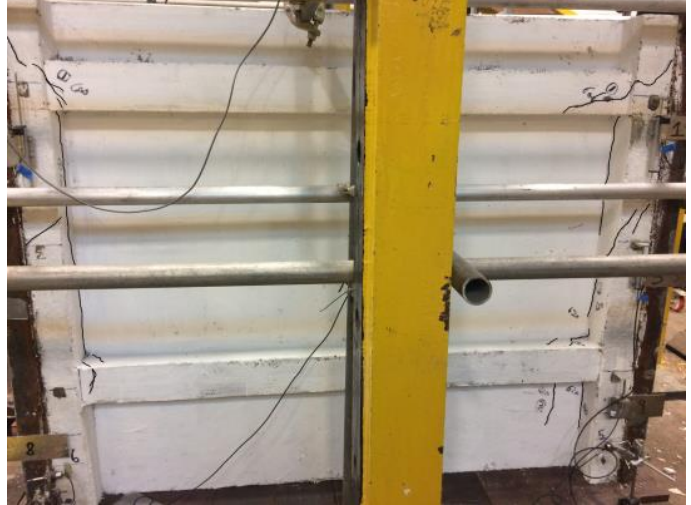

Fig. 8. Failure profile of concrete of specimen T1-NC.

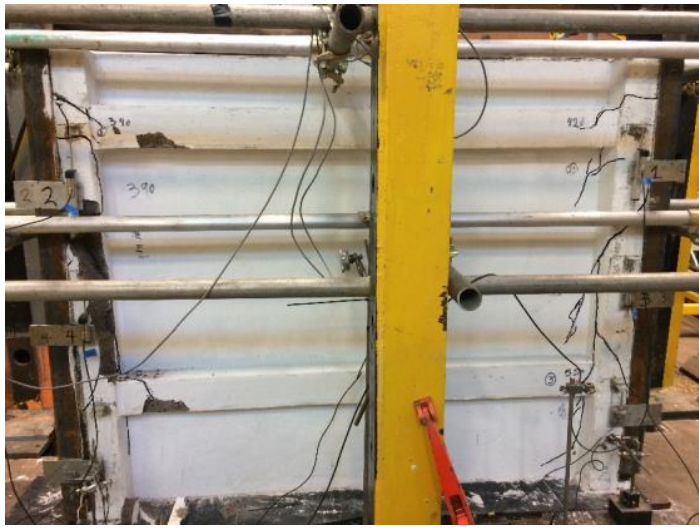

Fig. 9. Failure profile of concrete of specimen T1-LWC

\section{Concluding remarks}

The shear transferring mechanisms of the novel pre-fabricated shallow steel-concrete composite flooring system are different with the headed studs shear connectors, and have not been studied previously. The components of the proposed flooring system were selected according to the comparative LCA study with other prefabricated flooring system (Cofradal slab). The study demonstrated a reduction in the embodied energy and embodied carbon by about $17.94 \%$ and $9.33 \%$ respectively when compared with the Cofradal slab $[5,6]$. This paper presented experimental investigation of the shear transferring mechanisms, which were formed by the dowels and web-welded studs with two different types of concrete. In total, 2 full-scale push-out tests were carried out to study the shear connectors in terms of the shear resistance and behaviour.

The test results are evaluated and the following conclusions can be reached:
(1) Consistent behaviour is demonstrated by this type of the shear connection system with plastic deformations occurring before and after the ultimate load.

(2) Both dowels and web-welded stud shear connectors demonstrated the ductile behaviour and failure mode.

(3) The shear capacity of the connectors increases with the increasing of concrete strength.

\section{Acknowledgments}

The authors would like to acknowledge Lytag for their kind contribution in providing the material for the conduction of the full experimental campaign.

\section{References}

[1] Precast Concrete Flooring, BISON Precast Ltd., August 2007.

[2] ArcelorMittal Construction Benelux: Arval COFRADAL200®.

[3] Tsavdaridis KD, D'Mello C, Hawes M. Experimental Study of Ultra Shallow Floor Beams (USFB) with Perforated Steel Sections. Nordic Steel Construction Conference. 2009 - Malmö, Sweden.

[4] Huo BY, D'Mello C, Tsavdaridis KD. Experimental study and analytical study of push-out shear tests in Ultra Shallow Floor Beams. 34th IABSE Symposium International Association for Bridge and Structural Engineering, 22nd - 24th September 2010, Venice, Italy.

[5] Ahmed I, Tsavdaridis K, Neysari F. A new breed of sustainable ultra-lightweight and ultra shallow steel-concrete composite flooring system: life cycle assessment of materials. Jordan Journal of Civil Engineering, 2017.

[6] Ahmed I, Tsavdaridis K. A New Breed of Sustainable Ultra-lightweight and UltraShallow Steel-Concrete Composite Flooring System: LCA. In: Proceedings. Postgraduate Research Conference, Faculty of Engineering, 30-31 Mar 2017, Leeds, UK. University of Leeds.

[7] Eurocode 4. EN 1994-1-1, Eurocode 4: Design of Composite Steel and Concrete; 2004. 